\title{
Students' Mathematics Attitude towards Cooperative Learning Teams-Games-Tournament
}

\author{
Arsaythamby Veloo \\ School of Education and Modern \\ Languages \\ Universiti Utara Malaysia \\ Sintok, Malaysia \\ arsay@uum.edu.my
}

\author{
Faizahani Ab Rahman \\ School of Education and Modern \\ Languages \\ Universiti Utara Malaysia, \\ Sintok, Malaysia
}

\author{
Sitie Chairany \\ Madrasah Aliyah \\ Riau, Indonesia
}

\begin{abstract}
Teaching and learning mathematics with cooperative Team-Games-Tournament (TGT) has been associated to improving attitude, cooperation and sharing of knowledge of mathematics among students. This study aims toidentifythe attitudeof students onTGT cooperative learning. The participants ofthisstudywere32grade 11 students of Madrasah Aliyah Riau, Indonesia. Data collection was conducted based on post 1 testthat lasted forfiveweeksobtainedafter the pre and posttest1. The Mathematics test consists of10 items for comprehension andcommunicationwhich were adapted fromthe Indonesian National Examination(INE). Mathematicsattitudewas measured using20 itemswhich used to measure students' attitudes towards TGT [1]. The findings show that mathematicsattitude canimprovemathematics achievement.This study contributes to knowledge on enhancing effective teaching, active group activities, competition which improves attitudes among students and mutual help in the teaching of Mathematics. TGTencourages studentsand teachers tobe innovativeandcreativein improving theteachingand learning of Mathematics inthe classroom, andthiscan be advantageous to Madrasah Aliyahstudents when they compete withpublic schools' students inMathematics.
\end{abstract}

Keywords-attitude; mathematics achievement;cooperative teamgames-tournament

\section{INTRODUCTION}

Probabilities and functions are two mathematics topics that receive much attention in Madrasah Aliyah. The study of probabilities and functions is essential to explain facts or communicate ideas in mathematics understanding, explain relationships between concepts and apply concepts systematically, accurately and effectively to solve mathematical problems. A study of probabilities and functions also helps students to appreciate mathematics in daily life [2].One of the major objectives to be achieved in the teaching of probabilities and functions is to provide ample opportunities for students to develop and integrate their knowledge, skills and practices in mathematics understanding [3]. In the process of developing the students' abilities to understand mathematics, it is concluded that their mathematics communication will also improve. The ability to communicate will lead students to have a deep understanding of the relational and instrumental abilities in mathematics achievement [4]. However, it is noticed that Islamic education in Indonesia gives less attention to probability and mathematical functions andstudents were found to have difficulty in understanding probabilities and mathematical functions [5].

In relation to this understanding, it is equally important to have a positive. In this sense, attitude is defined as a way of thinking or a sense of feeling [6]. Attitude is action on an object as an answer from the stimulus generated by the situation described by the positive and negative aspects. Attitudes are acquired through certain objects that provide stimulus to him[7]. Attitude is the part that is acquired from positive or negative behavior through objects, concepts and people. In this case, attitude draws upon cognitive elements(confidence \& skills), affective domain (mood \& motivation) and behavior [8]. Assessment of attitude towards mathematics assessment is obtained through confidence, anxiety, excitement, motivation and values towards mathematics [9]. Mathematics performance is measured by students ' confidence. Whilst Math anxiety is measured by students' feelings. On the other hand, Mathematics fullfillment is measured by the ease with whuich students cooperate inmathematics and Mathematical motivation is measured by students ' interest in mathematics.

Attitudes can be seen from emotional habits, namely: (i) the students ' emotions in relation to experiences in mathematics, (ii) student emotions which are automatically drawn together towards mathematical concepts, (iii) an assessment of the situation of students who are expected to solve mathematics problems, and (vi) the value of mathematics related goals within the structure of students ' goals [10].Based on some of the research conducted 
previously, attitude can be defined as a way of thinking about objects, ideas, people and situations among students that comes through the process of observation and feedback in the learning of mathematics.Student attitude plays an important role in mathematics achievement. Attitude is something that is done through positive or negativeacts on an object. Attitude measurement can be conducted through students' attitudes to learning, the learning situation and the teacher [11].

Mathematics attitude has a positive effect on mathematics achievement. In this case, the ability of students to get motivated in understanding mathematics shows improvement. Attitude is an important component that promotes student interest in mathematics [12]. Students with interest and ability are able to solve mathematical problems satisfactorily. Normally, students who have the ability are those who are interested to learn. On the other hand, students who have a negative attitude towards their abilities often end up with no interest in learning mathematics[13, 14].High school students have positive attitudes towards mathematics and mathematics learning. The study also found that students have negative attitudes to solving challenging mathematics problems and the use of mathematics in daily life [15].

Positive attitude towards learning mathematics has no effect on the achievement of excellent students in the United States [16]. The same also applies to students in Japanwhich shows that students' attitudes toward mathematics do not contribute to significant differences in mathematics achievement.Based on theabove studies, the researchers focused on students' mathematics attitude towards cooperative learning. In here, Mathematics attitude refers to the way students evaluate an object, situation, and thoughts of others as a result of learning outcomes leading to feelings of like or dislike towards mathematics.

\section{Mathematics Attitudes towards Cooperative Learning}

There is a positive relationship between cooperative learning and Mathematics attitudes. This is apparent during group activities where students had opportunities to discuss, listening actively and critically to others views and opinions[17]. Conflicts within groups could also be resolved by working in groups through activities. TGT cooperative learning is effective as it showed positive attitude and this is measured without addressing individual differences [12]. TGT cooperative learning is apparent in the students mathematics attitudes through the use of group's appreciation and recognition and accountability of individuals [1]. "When students interact with their peers during the process of cooperative learning, conflicting opinions may arise due to the different level of mathematics conceptual competence among them. As expounded by Piaget's theory, conflicting opinions would bring about an imbalance in students cognitive processes. Consequently, students will work using the cognitive processes by understanding the concepts from a new perspective based on the discussions with their more competent peers" [18]. The effects of cooperative Simulation-Games Environment (SGE) on performance and mathematics attitudes of secondary school students in Nigeria and discovered that SGE cooperative is a teaching approach that influences performance and student's mathematics attitudes [19]. It is also found that in cooperative SGE approach, teachers motivated students and this resulted in the mathematics performance and positive attitude of students towards effective learning. Cooperative learning should be applied to all students disregarding their age as it has been proven to increase learning effectiveness [20].

\section{Teams-Games-Tournaments (TGT)}

TGT was developed as a method to be used in the field of problem-solving [21].It has a set method of learning which consists of four to five students who are heterogeneous in their ability, gender and race. Students receive instruction from teachers and each team competes in the weekly tournaments consists of representatives of each group of students with the same level of learning ability. The same level of learning ability among the group members means that students will compete with other students who have more or less the same level of ability. TGT cooperative learning emphasizes on cooperation between group members which contribute to improvement in group scores and individual scores [1, 22].

\section{II.METHOD}

The participants ofthisstudywere32Form 11 students of Madrasah Aliyah Riau, Indonesia selected from experimental group using cooperative learning in TGT. Mathematics test consists of10 items for comprehension andcommunicationwhich were adapted fromthe Indonesian National Examination(INE). The questionnaire used in this study was the mathematics attitude and cooperative learning in TGT. Mathematics attitude was measured using 20 items to measure student attitudes using TGT cooperative learning which was adapted from Slavin (1995). TGT cooperative learning attitude refers to the TGT cooperative learning components which are teachers' teaching, group activities, academic competitions, group appreciation and interaction. Data collection was conducted based on post 1 testthat lasted forfiveweeks each after the pre and posttest.

\section{Student attitudes toward cooperative learning TGT questionnaire}

Table 1 shows the mathematics attitude questionnaire for TGT cooperative learning consisting of six components such as teaching (2 items), group activities (6 items), solving mathematics questions using Worksheets (3 items), academic competition (4 items), honoring the group (4 items) and interaction during the competition (1 item). In order to facilitate the students in answering the 
questionnaire, the researchers decided to use an assessment list form for students. Students chose the answer they considered appropriate in the assessment list form. To provide feedback on each item submitted, students only had to mark $(\mathrm{X})$ in the boxes provided at the end of each statement. The Likert Scale method used for the questions was as 1 (very untrue), 2 (untrue), 3 (true), 4 (very true).

Attitudes towards cooperative learning of TGT were analyzed consisting of all the components found in the study. The first component was the "teaching". In this case, the item for the delivery of teaching materials found in item number 1 as a positive statement and item number 2 as a negative statement. The second component was "group activities". This component is related to group work and was measured in item number 3,5 and 6 in the form of positive statements and item number 4,7 and 8 as negative statements. The items related to solving mathematics questions using Worksheets were measured in item number 9 and 10 as positive statements and item number 11 as a negative statement. The fourth component was "academic competition". This item which is related to the implementation of academic competition was measured in item number 12 and 13 as positive statements and itemnumber 14 and 15 as negative statements. The fifth component was "honoring the group". This item, related to individual and group assessment, was measured as item number 16,17 and 18 as positive statements an $\mathrm{d}$ item number 19 as a negative statement. The sixth component on "interaction" which is related to interaction during the competition was measured as item number 20 as a positive statement.

TABLE 1 MATHEMATICS ATTITUTE QUESTIONNAIRE FORTGT COOPERATIVE LEARNING

\begin{tabular}{|c|l|l|c|}
\hline No & $\begin{array}{l}\text { Cooperative } \\
\text { learning (TGT) }\end{array}$ & \multicolumn{1}{|c|}{ Statement } \\
\hline 1 & Teaching & $\begin{array}{l}\text { Positive Statement 1 } \\
\text { Negative statement 2 }\end{array}$ & 2 \\
\hline 2 & Group activities & $\begin{array}{l}\text { Positive Statement 3, 5, 6 } \\
\text { Negative statement 4, 7, 8 }\end{array}$ & 6 \\
\hline 3 & $\begin{array}{l}\text { Solving } \\
\text { mathematics } \\
\text { questions using } \\
\text { Worksheets }\end{array}$ & $\begin{array}{l}\text { Positive Statement 9 and } \\
10 \\
\text { Negative statement 11 }\end{array}$ & 3 \\
\hline 4 & $\begin{array}{l}\text { Academic } \\
\text { competition }\end{array}$ & $\begin{array}{l}\text { Positive Statement 12 and } \\
13 \\
\text { Negative statement 14 and } \\
15\end{array}$ & 4 \\
\hline 5 & $\begin{array}{l}\text { Honoring the } \\
\text { group }\end{array}$ & $\begin{array}{l}\text { Positive Statement 16, 17 } \\
\text { and 18 } \\
\text { Negative statement 19 }\end{array}$ & 4 \\
\hline 6 & $\begin{array}{l}\text { Games Interaction } \\
\text { competition }\end{array}$ & \begin{tabular}{l} 
Positive Statement 20 \\
\hline
\end{tabular} & 1 \\
\hline
\end{tabular}

\section{FINDINGS}

Student Attitudes toward Cooperative Learning TGT Mathematics attitude using TGT cooperative learning consist of six components such as teaching, group activities, solving mathematics questions using worksheets, academic competition, honoring the group and interaction during the competition. Student attitudes

\section{TABLE 2 TEACHING USING TGT}

\begin{tabular}{|c|l|c|}
\hline Item & \multicolumn{1}{|c|}{ 1.Teaching Using TGT } & Mean \\
\hline 1 & $\begin{array}{l}\text { Studying in groups really helped me to study } \\
\text { mathematics }\end{array}$ & 3.69 \\
\hline 2 & $\begin{array}{l}\text { Brief delivery of learning materials confuses } \\
\text { me }\end{array}$ & 2.53 \\
\hline
\end{tabular}

toward TGT cooperative learning based on teaching using TGT shows positive attitude for 'studying in groups really helped me to study mathematics'(item 1). Item 2 (brief delivery of learning materials confuses me) which is a negative statement showed low mean indicating that students were not confused with the brief delivery of teaching content using TGT (Table 2).

\section{TABLE 3 GROUP ACTIVITIES}

\begin{tabular}{|c|l|c|}
\hline Item & \multicolumn{1}{|c|}{ 2. Group activities } & Mean \\
\hline 3 & $\begin{array}{l}\text { I prefer to discuss and cooperate when doing } \\
\text { problem-solving }\end{array}$ & 3.59 \\
\hline 4 & Learning in groups is less effective & 1.88 \\
\hline 5 & $\begin{array}{l}\text { In group learning, I become more daring to ask } \\
\text { questions. }\end{array}$ & 3.38 \\
\hline 6 & $\begin{array}{l}\text { I will really perform my tasks so that my } \\
\text { group becomes the best }\end{array}$ & 3.50 \\
\hline 7 & $\begin{array}{l}\text { Ineed not put in effort for group assignments } \\
\text { because of the excellent partners }\end{array}$ & 1.88 \\
\hline 8 & $\begin{array}{l}\text { Iprefer to work individually on questions } \\
\text { rather than in groups }\end{array}$ & 2.19 \\
\hline
\end{tabular}

Table 3 show that students enjoy when they discuss and cooperate to solve problems (item 3), and are willing to ask questions and express opinions (item 5). This is further supported by item 6 , in which all these statement that students seriously worked on questions to become excellent groups. These results indicate that group learning is effective for students to understand the learning material. As for item 4, 7 and 8, which are negative statements, all showed means less than 2.5, indicating that the students did not agree or felt that those claimed statement will not help with them performing well in mathematics. The negative statements also carry negative attitudes that would not contribute to the effective learning of the students of the madrasah.

At the completion of the Worksheet math questions, students who chose item 9 (I try to work out the questions to the best of my ability) and item 10 (Learning using Worksheets can help me to understand the learning materials) which all these statement that students seriously 
worked on questions to become excellent in group activities. These results show that many students complete the questions on

TABLE 4 SOLVING MATHEMATICS QUESTIONS USING WORKSHEETS GROUP ACTIVITIES

\begin{tabular}{|c|l|c|}
\hline Item & \multicolumn{1}{|c|}{$\begin{array}{c}\text { 3. Solving mathematics questions using } \\
\text { worksheets }\end{array}$} & Mean \\
\hline 9 & $\begin{array}{l}\text { I try to work out the questions to the best of } \\
\text { my ability }\end{array}$ & 3.25 \\
\hline 10 & $\begin{array}{l}\text { Learning using Worksheets can help me to } \\
\text { understand the learning materials }\end{array}$ & 3.22 \\
\hline 11 & $\begin{array}{l}\text { Learning } \text { using Worksheets makes it difficult } \\
\text { for me to understand learning materials }\end{array}$ & 2.03 \\
\hline
\end{tabular}

Worksheet earnestly, so that it can help a friend to understand a lot of learning materials being studied. While item 11, students who chose "Learning using Worksheets makes it difficult for me to understand learning"showed mean less than 3 , which is a negative statement (Table 4).

Table 5, shows that the implementation of academic competition component under item 12 and 13. These items demonstrates that most of the students who are motivated to learn mathematics and have a sporting attitude through student academic competitions. Nevertheless, there were 6 students response for item 14 (I feel panicky when I follow competitions) and item 15(Academic competitions do not produce any effect on me). This means that academic competition activities do not influence mathematics achievement for this small number of students.

\section{TABLE 5 ACADEMIC COMPETITION}

\begin{tabular}{|c|l|c|}
\hline Item & \multicolumn{1}{|c|}{ 4. Academic competition } & Mean \\
\hline 12 & $\begin{array}{l}\text { Academic competitions motivate me to study } \\
\text { mathematics }\end{array}$ & 3.31 \\
\hline 13 & $\begin{array}{l}\text { Academic competitions train students to be } \\
\text { sporting }\end{array}$ & 3.28 \\
\hline 14 & Ifeel panicky when I follow competitions & 1.94 \\
\hline 15 & $\begin{array}{l}\text { Academic competitions do not produce any } \\
\text { effect on me }\end{array}$ & 2.06 \\
\hline
\end{tabular}

For the individual and group assessment components, the results for items 16 (I'll try to get the highest score in competitions which will contribute to the group scores), item 17 (I try to motivate my peers in the group to achieve the highest scores) and item. 18 (The evaluation on students is objective) indicate that students try to get the highest scores in the academic competitions, which will contribute to the group scores. The results for items 19 indicate that the evaluation of the academic competitions provide support for students in terms of building confidence in them towards performing well in mathematics (Table 6).

\section{TABLE 6 HONORING THE GROUP}

\begin{tabular}{|l|l|c|}
\hline Item & \multicolumn{1}{|c|}{ 5. Honoring the group } & $\begin{array}{c}\text { Mea } \\
\mathrm{n}\end{array}$ \\
\hline 16 & $\begin{array}{l}\text { I'll try to get the highest score in competitions } \\
\text { which will contribute to the group scores }\end{array}$ & 3.34 \\
\hline 17 & $\begin{array}{l}\text { I try to motivate my peers in the group to } \\
\text { achieve the highest scores }\end{array}$ & 3.28 \\
\hline 18 & The evaluation on students is objective & 3.19 \\
\hline 19 & $\begin{array}{l}\text { The evaluation during the academic competition } \\
\text { made me less confident }\end{array}$ & 2.22 \\
\hline
\end{tabular}

For games interaction competition component, all students chose item number 20 which means that with the table games interaction, students worked harder. The findings from Item number 20, which is about TGT cooperative learning, show that students have a positive attitude towards TGT cooperative learning (Table 7).

TABLE 7 GAMES INTERACTION COMPETITION

\begin{tabular}{|c|c|c|}
\hline Item & \multicolumn{1}{|c|}{ 6. Games interaction competition } & Mean \\
\hline 20 & $\begin{array}{l}\text { My position in the table games makes me } \\
\text { study more diligently and be more interactive }\end{array}$ & 3.22 \\
\hline
\end{tabular}

\section{Cooperative Learning Assessment Mathematics and Student Attitudes}

This study found that TGT cooperative learning can improve students' mathematics attitude. Thus, TGT Cooperative learning can be regarded as a useful tool for developing a positive attitude towards learning. Students who learn mathematics very often became disappointed with individual work, but will improve and gain confidence when they worked in groups and this is how cooperative learning helps in improving students' mathematics attitude. A positive attitude in mathematics can help students share mathematical ideas.

The attitude scores of mathematics in TGT cooperative learning is higher compared to negative statement in attitude. There is a positive impact on attitudes in the cooperative learning of mathematics [12]. It can be seen that when students work in groups, they have a chance to speak, actively listen to the arguments made by classmates and work through conflict.

Cooperative learning can improve mathematics attitude and the teacher's role in here is not only as a facilitator of student learning in mathematics, but also as a motivator to students' academic achievement[19]. This study also discovered that the ability to think, to cooperateand the positive attitude shown by teachers towards learning and a high level of responsibility were all appreciated by students. This inevitably leads to student motivation and will work to balance the cognitive processes by understanding the mathematics concepts with their peers $[1,18,22]$.

The findings also showed that the interaction that occurs during cooperative learning can be further developed. It creates a more fun learning environment and gives students more opportunities to develop students' cognitive abilities. This is further supported where 
cooperative learning is advantageous for students to interact with and promote a restructuring of student thinking which includes ways to examine, summarize, clarify and give examples [20]. This proves that the use of cooperative learning helps to develop more meaningful skills when compared to individual learning using TGT approach.

\section{CONCLUSION}

TGT cooperative learning has been proven to improve attitude, interest, motivation and knowledge sharing amongst students as compared to conventional learning. The teaching and learning of mathematics using TGT in classrooms illustrate that the interactions between students and students and teachers are well-developed. Additionally, TGT is proven to encourage both students and teachers to be innovative and creative in their teachings and learnings and this could be regarded as a method of teaching Mathematics in Madrasah Aliyah.

\section{REFERENCES}

[1] R. E. Slavin.Cooperative learning theory, research, and practice ( $2^{\text {nd }}$ ed.). America: 1995, Allyn and Bacon

[2] N. Ulya.Upaya meningkatkan kemampuan penalaran dan komunikasi matematik siswa SMP/MTS melalui pembelajaran kooperatif Tipe Teams-Games-Tournaments (TGT).(Unpublished master's thesis). 2007, Universitas Pendidikan Indonesia, Bandung.

[3] A. Elizabeth, van Es., \&J. Conroy. Using the performance assessment for California teacher to examine pre-service teacher' conceptions of teaching mathematics for understanding. Issues in Teacher Education. 2009, University of California, Irvine.

[4] Supriyono. Developing Mathematical Learning Device Using Ttw (Think- Talk-Write) Strategy Assisted By Learning Cd To Foster Mathematical Communication. Paper presented at International Seminar and the Fourth National Conference on Mathematics Education, 2011, Yogyakarta.

[5] O. Darnius. Pemakaian peluang dalam membuat keputusan: Suatu Tinjauan dalam Masalah Grosir. Jurnal FMIPA, 2004, Universitas Sumatera Utara.

[6] S. Johnsen. Improving achievement and attitude through cooperative learning in math class .Action Research Projects. 2009, University of Nebraska-Lincoln.

[7] B. Susetyo. Hubungan motivasi, minat, sikap dengan prestasi belajar fisika, matematika, kimia, dan biologi di FMIPA dan EPMIPA. Laporan Penelitian,2004, Jakarta.

[8] L. R. Aiken. Attitude measurement and research. In D. A. Payne (Ed.). Recent Developments in Afictive Measurement. 1980.San Francisco: Jossey-Bass.

[9] M. Tapia, \&G. Marsh. An instrument to measure mathematics attitudes. Academic Exchange, 2004, pp16-21.

[10] M. S. Hannula. Attitude towards mathematics: Emotions, expectations and values. 2002 .
[11] Marsigit. Konsep dasar Kurikulum 2004 (matematik) Sekolah Menengah Atas/Madrasah

Aliyah Negeri. Jurnal PMIPAUniversitas Negeri Yogyakarta, 2004, pp. 1-10.

[12] V. Arsaythamby, V., \& Sitie, Chairaini. Fostering students' attitudes and achievement in probability using Teams-GamesTournaments. Paper Conference on Learning, Teaching \& Educational Leadership, (2012, October). Belgium.

[13] T. Steyn, \&J. G. Maree. Graphical exploration of twodimensional functions - an aid to mastering fundamental calculus concepts. South African Journal of Education, 22(4), 2003, pp47-55

[14] V.Arsaythamby, \& M. Shamsuddin. Hubungan sikap, kebimbangan dan tabiat pembelajaran dengan pencapaian matematik tambahan. Asia Pacific Journal of Education and Education, 26(1), 2011, pp.15-32.

[15] L. Fan, \&K. S. Quek. Assessing Singapore students' attitudes toward mathematics and Mathematics learning. Findings from a Survey of Lower Secondary Students, Nanyang Technological University, 2005, Singapore.

[16] C. Papanastasiou. Effect of attitude and beliefs on mathematics achievement. Studies in

$$
\text { Educational Evaluation, } 26 \text { (1 ), 2000, pp27-42. }
$$

[17] L. B. Briana. Enhancing student achievement through cooperative learning at the elementary level (Master Thesis), Northern Michigan University. 35, 2010, pp395-426.

[18] V. Arsaythamby, Ruzlan Md-Ali, \& Sitie Chairany. Using Cooperative Teams-Game-Tournament in11 Religious School to Improve Mathematics Understanding and communication. Malaysian Journal of Learning \& Instruction, 13 (2), 2016 , pp. 97-124.

[19] M. K. Akinsola. The effect of simulation-games environment on students achievement in and attitudes to mathematics in secondary schools. The Turkish online Journal of Educational Technology, 6(3), 2007, pp.113-119.

[20] S. Kagan. Kagan structures-not one more program. A better way to teach any program. Kagan Online Magazine,2000, pp.18.

[21] Edwards, K. J., \& De Vries, D. L. (1972). Learning games and student teams: Their effects on

student attitudes and achievement (Report No. 147). Baltimore: Center for Social Organization of Schools, Johns Hopkins University.

Educational Studies in Mathematics, 49, pp. 25 - 46.

[22] Mahony, M. (2006). Teams-Games-Tournament (TGT) cooperative learning and review. NABT

Coference.Momahony@uts.utoronto.ca. 